www.jmscr.igmpublication.org

Impact Factor 3.79

Index Copernicus Value: 5.88

ISSN (e)-2347-176x ISSN (p) 2455-0450

crossref DOI:_http://dx.doi.org/10.18535/jmscr/v4i1.11

Journal Of Medical Science And Clinical Research

\title{
Red Cell Parameters in G6PD Deficient Individuals during Normal Steady State
}

Authors

\section{Hetal Patel ${ }^{1}$, Poonam Savalani ${ }^{1}$, Hiren Dhanani ${ }^{1}$, Ramesh Z Patel ${ }^{1}$, Sanmukh R Joshi ${ }^{2}$}

${ }^{1}$ Department of Pathology, Medical College, Vadodara and ${ }^{2}$ Lok Samarpan Blood Bank, Surat drhetalg27@gmail.com,p_savlani@yahoo.com,drhirenjd@gmail.com,dr.rzpatel@gmail.com,

\section{Corresponding Author}

\section{Dr. Sanmukh R. Joshi}

Lok Samarpan Blood Bank, Mira Nagar, Opp Saurashtra Patidar Hall. Mini Bazar,

Varachha Road, Surat-395006, Gujarat State, India

Email: sanmukhj@yahoo.com, PhoneNo.00917715915574

\section{Abstract}

Background: G6PD enzyme deficiency has X-linked inheritance with variable prevalence in different population groups. Deficient subjects enjoy normal health unless were exposed to oxidative stress that yields haemolytic crises and may lead to fatalities.

Aim/objective: Few reports available on haematological parameters among G6PD deficient subjects in steady state; the issue is addressed in present report.

Research design: Pairs of spouses from Vatalia Prajapati community, known for high prevalence of G6PD deficiency, were selected for prospective analysis. Measurement of red cell indices and quantitative assay for G6PD enzyme were carried out using automated devices. The parameters were correlated among the subjects classified as per level of enzyme activities (as EU/gHb at $37^{\circ} \mathrm{C}$ ) shown, i. e. Normal, >9 (male and female); Heterozygote, 2.75 - 8.99 (female) and Deficient, <2.75 (male hemizygote and female homozygote). The statistical analysis was carried out using Microsoft Excel 2010 and online software.

Results: Among 148 subjects studied, 40 of 77 male and 25 of 71 female were deficient for G6PD enzyme. Between normal and enzyme deficient groups, the male displayed significant difference in the mean values for $R B C$ count, $H b$ and $P C V$, while the female showed significant difference only in the RBC count. Interestingly, the mean values for all the parameters significantly differ among the heterozygote and homozygote for G6PD deficiency. Increased MCV was significantly associated with heterozygote as compared to the normal.

Conclusion: Although G6PD deficiency does not show any illness in normal steady life, the red cell parameters do show some deviation from normal.

Key words: G6PD deficiency, red blood cell indices/parameters.

\section{Introduction}

G6PD deficiency is an inherited trait having variable prevalence in different caste and tribal population groups in Gujarat State of India ${ }^{[1-4]}$. Subjects with G6PD deficiency suffer no ill- effect, though an individual with class I variant may display a picture of chronic non-spherocytic haemolytic anaemia ${ }^{[5]}$. Otherwise in normal health, an intake of oxidant drugs or an exposure to oxidant chemicals, the subjects with the enzyme 
deficiency develops haemolytic crises of variable severity, sometimes resulting into fatal outcome ${ }^{[5]}$. G6PD deficiency is an X-linked character. A G6PD deficient male is in hemizygous state and may suffer from an adverse effect of oxidative insults. The female in heterozygous state of the enzyme deficiency may have spectrum of dual red cell population: a half of the red cells with enzyme deficiency and others half with normal level of enzyme $^{[6]}$. Under an oxidative stress, the enzyme deficient red cells are prone to get destroyed, while the remainder, with normal compliment of the enzyme, remain unaffected and render the clinical manifestations milder.

Unlike haemoglobinopathies such as cases with sickle cell anaemia or thalassaemia major, G6PD deficiency seldom presents a severe anaemia in steady state. Apart from being a low level, the G6PD enzyme is unstable to an extent to yield a shortened life-span of red cell ${ }^{[7]}$ and may result into subnormal red cell parameters. There are scanty reports available in literature on haematological parameters associated among the G6PD deficient subjects during their steady state be it in hemizygote male or in homozygote or heterozygote female. We present here our data on haematological parameters among the three different categories of G6PD enzyme status among the subjects from Vataliya Prajapati community that is known to have a high prevalence of G6PD deficiency of Mediterranean type $^{[4,8]}$.

\section{Materials and Methods}

Subjects: Pairs of spouse (husband-wife) from Vatalia Prajapati community living in the city of Surat, Gujarat were selected for this prospective study. Blood specimen, in $3 \mathrm{ml}$ quantity, was collected in vacutainer tubes containing EDTA. The red cell indices were measured on Sysmex KX21 analyser (Sysmex-Transasia, Mumbai, India), pre-calibrated with commercially available red cell controls. Each specimen was subjected to quantitative assay for G6PD enzyme using inhouse reagents prepared and method standardised at $37^{\circ} \mathrm{C}$ as per ICSH $(1979)^{[9]}$ on chemistry analyser Microlab 200 (Merck, Germany). The subjects under study were classified as per level of enzyme activities (as EU/gHb) displayed, i. e. Normal, >9 (in both male and female); Heterozygote, 2.75 - 8.99 (in female carriers), and Deficient, <2.75 (in male hemizygote and female homozygote). Haematological parameters studied included RBC count, $\mathrm{Hb}, \mathrm{PCV}, \mathrm{MCV}, \mathrm{MCH}$, $\mathrm{MCHC}$ and RDW\%CV. The statistical analysis was carried out on Microsoft Excel 2010. Excluded from analysis were the cases having microcytosis and/or normocytic anaemia which included $\beta$-thalassaemia trait/ iron deficiency. The statistical calculations were carried out online ${ }^{[10]}$.

\section{Results}

A total of 148 subjects were studied for quantitative analysis for G6PD enzyme activity. Of these, 77 subjects were male and 71 were female. Among the male, 37 subjects showed normal activity, while 40 individuals displayed deficiency of the enzyme. Among the female, 38 had normal, 25 had subnormal and remaining 8 were deficient for the enzyme.

Table 1 shows comparison in haematological values - RBC counts, $\mathrm{Hb}$ and $\mathrm{PCV}$-among various categories of subjects for their G6PD enzyme levels.

Among the male, the mean values for RBC count, $\mathrm{Hb}$ and $\mathrm{PCV}$, differed significantly $(\mathrm{p}<0.0001$, $=0.023,=0.0067$ respectively) between normal and enzyme deficient subjects. However, among the female, only the values for RBC count differed significantly between normal and enzyme deficient homozygote $(\mathrm{p}=0.0018)$. The values for $\mathrm{Hb}$ and $\mathrm{PCV}$, however, did not differ between normal and enzyme deficient homozygote.

Interestingly, there was significant difference between enzyme deficient heterozygote and enzyme deficient homozygote for mean values with respect to all the three parameters. This paradoxical result may be attributed to a smaller sample size of the homozygote group.

As normal range for red cell indices, viz. MCV, 


\section{JMSCR Vol||04||Issue||01||Page 8854-8858||January}

$\mathrm{MCH}, \mathrm{MCHC}$ and RDW\%CV, for both male and female subjects was found to have the same statistics, further analysis was carried out among the three groups viz. those with normal enzyme activity (male + female, $n=75$ ), subnormal enzyme activity (female heterozygote, $n=25$ ) and deficient enzyme activity (male hemizygote + female homozygote, $n=48$ ). The results are summarized in Table 2.

Increased MCV was significantly associated with heterozygote as compared to the normal individuals. However, $\mathrm{MCH}, \mathrm{MCHC}$ and RDW\%CV were not significantly different among these two. On the other hand, MCV, MCH and RDW\%CV were significantly different among the heterozygote and deficient groups. So also is true for these three parameters being significantly different between normal and deficient groups ( $\mathrm{p}$ $<0.0001)$. It is interesting to note that MCHC appears to be an inert index and is not significantly different between any of these groups.

Table 1. Absolute RBC count, Haemoglobin and PCV values in various categories of G6PD enzyme status

\begin{tabular}{|c|c|c|c|c|c|}
\hline \multirow{3}{*}{$\begin{array}{l}\text { Red cell } \\
\text { Parameters }\end{array}$} & \multicolumn{2}{|l|}{ Males (n 77) } & \multicolumn{3}{|l|}{ *Female (n 71) } \\
\hline & $\begin{array}{l}\text { G6PD Normal, } \\
\text { (n 37) }\end{array}$ & $\begin{array}{l}\text { G6PD Deficient, } \\
\text { Hemizygote } \\
\text { (n 40) }\end{array}$ & $\begin{array}{l}\text { G6PD Normal, } \\
\text { (n 38) }\end{array}$ & $\begin{array}{l}\text { G6PD } \\
\text { Heterozygote } \\
\text { (n 25) }\end{array}$ & $\begin{array}{l}\text { G6PD Deficient, } \\
\text { Homozygote } \\
\text { (n 8) }\end{array}$ \\
\hline & $($ Mean \pm SD $)$ & $($ Mean \pm SD $)$ & $($ Mean \pm SD $)$ & $($ Mean \pm SD) & $($ Mean \pm SD $)$ \\
\hline \multirow{2}{*}{$\begin{array}{l}\text { RBC } \\
\left(\times 10^{6} / \mu \mathrm{L}\right)\end{array}$} & $5.18 \pm 0.43$ & $4.69 \pm 0.54$ & $4.5 \pm 0.37$ & $4.4 \pm 0.29$ & $4.04 \pm 0.34$ \\
\hline & \multicolumn{2}{|c|}{$\mathrm{p}<0.0001$} & & \multicolumn{2}{|c|}{$\mathrm{p}=0.0062$} \\
\hline \multirow[t]{2}{*}{$\mathrm{Hb}(\mathrm{g} / \mathrm{dL})$} & $15.29 \pm 1.04$ & $14.74 \pm 1.02$ & $13.08 \pm 0.8$ & $13.16 \pm 0.71$ & $8 \pm 0.42$ \\
\hline & \multicolumn{2}{|c|}{$\mathrm{p}=0.023$} & & \multicolumn{2}{|c|}{$\mathrm{p}=0.0352$} \\
\hline \multirow[t]{2}{*}{ PCV (\%) } & $45.71 \pm 2.63$ & $43.81 \pm 3.29$ & $39.39 \pm 2.03$ & $39.92 \pm 1.8$ & \pm 1.8 \\
\hline & \multicolumn{2}{|c|}{$\mathrm{p}=0.0067$} & & \multicolumn{2}{|c|}{$\mathrm{p}=0.0266$} \\
\hline
\end{tabular}

"RBC count - Normal v/s Deficient: $\mathrm{p}=0.0018$; the rest of the correlations were non-significant

Table 2. Red cell indices in various categories of G6PD enzyme status ( $n=148)$

\begin{tabular}{|c|c|c|c|}
\hline \multirow[t]{2}{*}{ Red cell indices } & $\begin{array}{l}\text { Normal G6PD activity } \\
(\text { Male + Female }) \\
(n=75)\end{array}$ & $\begin{array}{l}\text { Subnormal G6PD activity } \\
\text { (female, heterozygote) } \\
(\mathrm{n}=25)\end{array}$ & $\begin{array}{l}\text { Deficient Enzyme activity } \\
(\text { male }+ \text { Female }) \\
(\mathrm{n}=48)\end{array}$ \\
\hline & Mean \pm SD & Mean \pm SD & Mean \pm SD \\
\hline \multirow[t]{2}{*}{ MCV (fl) } & $87.91 \pm 4.92 *$ & $90.89 \pm 4.43$ & $94.21 \pm 5.98$ \\
\hline & & \multicolumn{2}{|c|}{$\mathrm{p}=0.017$} \\
\hline \multirow[t]{2}{*}{$\mathrm{MCH}$ (pg/RBC) } & $29.39 \pm 2.12 *$ & $30.04 \pm 1.84$ & $31.66 \pm 2.94$ \\
\hline & & \multicolumn{2}{|c|}{$\mathrm{p}=0.0149$} \\
\hline \multirow[t]{2}{*}{$\mathrm{MCHC}(\mathrm{g} / \mathrm{dL})$} & $33.39 \pm 1.12$ & $32.97 \pm 0.98$ & $33.56 \pm 1.35$ \\
\hline & & \multicolumn{2}{|c|}{$\mathrm{p}=0.0556$} \\
\hline \multirow[t]{2}{*}{ RDW\%CV } & $13.48 \pm 0.98^{*}$ & $13.14 \pm 0.79$ & $12.38 \pm 0.60$ \\
\hline & & \multicolumn{2}{|c|}{$\mathrm{p}<0.0001$} \\
\hline
\end{tabular}

*Difference in MCV, MCH and RDW between normal and deficient groups highly significant $(\mathrm{p}<0.0001)$

\section{Discussion}

G6PD enzyme deficiency is an $\mathrm{X}$-linked recessive trait being expressed among the males as hemizygote phenotype. Subjects with deficient enzyme do not suffer ill-effect in normal steady state, though a very mild chronic haemolysis may be present in hemizygote male ${ }^{[5]}$. However an exposure to oxidants results in haemolytic crises of variable severity, sometimes with fatal outcome. Female, carrying the deficient gene are being protected by its normal G6PD gene in heterozygote state leading to normal healthy life. Because heterozygote female exhibit mosaic of red cells with some having decreased amount of 
enzyme and the others with normal compliment of the same ${ }^{[6]}$. While red cells with enzyme defect would get destroyed in offending oxidant environment, those with normal level of enzyme would remain unaffected, thus protecting the subject. It has been observed that a low level of this enzyme reduces the red cell life-span to 100 days ${ }^{[7]}$. Besides, the G6PD enzyme, encoded by the Mediterranean variant gene, is unstable in nature $^{[11]}$. In spite of these two anomalies, the subject does not manifest anaemia in the steady state, contrary to what usually seen in cases with haemoglobinopathies like sickle cell anaemia or $\beta$ - thalassaemia major.

The present report deals on haematological parameters studied in the three different phenotypes for G6PD enzyme defect, i.e. hemizygote (male), homozygote (female) and heterozygote (female) in comparison with normal subjects taken from the same Vataliya Prajapati community. This community was reported for a high prevalence of G6PD deficiency ${ }^{[4]}$ of the Mediterranean type ${ }^{[8]}$.

Gupte et al. ${ }^{[12]}$ observed mild anaemia among the G6PD deficient phenotype with decreased MCV $(<75 \mathrm{fl})$ and $\mathrm{MCH}(<27 \mathrm{pg})$ and attributed to iron deficiency or $\beta$-thalassaemia trait. In our study, we have addressed this issue by eliminating from analysis the cases showing diagnostic features of thalassaemia or iron deficiency anaemia. An increased MCV value among the G6PD deficient subjects was thought to be due to folate deficiency.

Although there is no apparent consanguinity seen among the Vataliya Prajapati, a possibility of inbreeding cannot be ruled out because of the strict endogamous marriage practice followed within the small community of limited population size. Like many other Hindu communities in India, marriage is prohibited between the family harbouring same surnames, called 'gotras'. In order to avoid repeat member from a family, we recruited spouses (pairs of husband-wife) only for our study.

It appears that, as the level of enzyme deficiency increases, the values for $\mathrm{MCV}$ and $\mathrm{MCH}$ is also increase. This probably compensates the reduced level of RBC count in deficient group vis-a-vis $\mathrm{Hb}$ and PCV values. This probably reflects an increased demand met by proliferating bone marrow. Surprisingly, RDW\%CV is significantly lower in deficient groups, suggesting that the RBC population is more homogenous in deficient group than the normal group! There are scanty reports available in literature on haematological parameters studied among the G6PD deficient phenotypes during steady state. Gupte et al. ${ }^{[12]}$ had also observed an increased MCV.

Normal G6PD enzyme has a half-life of about 60 days in $v i v o^{[13]}$, but it still remains good through the full life of red cell, as being a "reserve" enzyme that gets activated only in an event of oxidising challenge, hence can save the red cell from oxidising damage.

The Mediterranean variant, which is present in the population under study, has the activity $\leq 10 \%$ of the enzyme in normal ${ }^{[11]}$. If we consider 10 $\mathrm{EU} / \mathrm{gHb}$ (Enzyme Units per gram of $\mathrm{Hb}$ ) arbitrarily as $100 \%^{[14]}$, then a deficient person can survive with $0.2 \mathrm{EU} / \mathrm{gHb}(2 \%)$ without overt manifestation of this deficiency. In our study, the average G6PD was $0.68 \mathrm{EU} / \mathrm{g} \mathrm{Hb}$ in the deficient group (hemizygote male and homozygote female). This may explain an absence of clinical symptoms of anaemia. The cause of subnormal values of $\mathrm{Hb}$ in these individuals could be attributed to a reduced life-span of red cells due to very low enzyme in old cell population as well as to the unstable nature of this mutant enzyme ${ }^{[5]}$.

\section{References}

1. Baxi AJ, Parikh NP and Jhala HI (969) Incidence of Glucose-6-phosphate dehydrogenase Deficiency in three Gujarati populations. Human Genet 8:62.

2. Mehta BC, Baxi AJ, Bhatia HM, Joshi SR, Dave VB, Vaidya PN and Patel JC (1971) Glucose-6-Phosphate dehydrogenase deficiency in the Bhanushali Community A survey. Indian J Med.Sci, 25(4):229-230. 
3. Joshi SR, Mehta MM, Mehta DM, Bapat JP, Baxi AJ, and Bhatia HM (1978) Genetic studies in three tribal groups of Dadra and Nagar-Haveli Region in Western India. Indian J. of Physical Anthropology and human Genetics, 4 (2):133-140.

4. Joshi SR, Patel RZ, Patel HR, Sukumar S, Colah RB (2001) High prevalence of G6PD deficiency in VataliyaPrajapati community in western India. Haematologia; 31:57-60.

5. WHO (1989) Working Group: Glucose-6phosphate dehydrogenase deficiency: an update. Bulletin of the World Health Organization, 67 (6): 601-611.

6. Beutler E, Yeh M, Fairbanks VF.(1962) The normal human female as a mosaic of $\mathrm{X}$-chromosome activity. Studies using the gene for G6PD deficiency as a marker. Proc Natl Acad Sci USA 48:9-16.

7. Sanna G, Frau F, Melis A, Galanello R, De Virgiliis $S$ and Cao A (1980) Interaction between the glucose-6-phosphate dehydrogenase deficiency and thalassaemia genes at phenotype level. British Journal of Haematology 44:555-561.

8. Sukumar S, Colah B, Mohanty D, Joshi SR (2001). A single mutation is responsible for the high prevalence of G6PD deficiency in Vataliya Prajapati -An endogamous caste group from western India. Am J Hematology;67:218-219.

9. Beutler E, Blume KG, Kaplan C, Löhr GW, Ramot B, Valentine WN (1979) International Committee for Standardization in Haematology: recommended screening test for glucose-6phosphate dehydrogenase (G-6-PD) deficiency. Br J Haematol.; 43:469-477.

10. GraphPad software, QuickCalcs (online) (http://www.graphpad.com/quickcalcs/ttest 1/?Format=SD, (accessed on August 10,
2014).

11. Beutler E (1972) Glucose-6-phosphate dehydrogenase deficiency. In: Stanbury JB, Wyngaarden JB, Fredrickson DSeds. The metabolic basis of inherited disease. $3^{\text {rd }}$ ed. New York, McGraw-Hill.

12. Gupte SC, Shaw AN, Shah KC. (2005) Hematological Findings and Severity of G6PD Deficiency in Vataliya Prajapati Subjects. Journal of Association of Physicians of India, 53:1027-1030.

13. Piomelli S, Corash LM, Davenport DD, Miraglia J and Amorosi EL(1968) In vivo lability of glucose-6-phosphate dehydrogenase in GD A- and Gd Mediterranean deficiency. J Clin Invest47:940-948.

14. Angelo Minucci, Bruno Giardina, Cecilia Zuppi and Ettore Capoluongo. (2009). Glucose 6-phosphate Dehydrogenase laboratory Assay: How, When and Why? International Union of Biochemistry and Molecular Biology (IUBMB Life), 61(1):27-34. 